\title{
Proteomic Analysis of Plasma Proteins after Low-Level Laser Therapy in Rats
}

\author{
R. KILIK ${ }^{1}$, P. BOBER ${ }^{2}$, I. ROPOVIK ${ }^{3}$, R. BEŇAČKA ${ }^{4}$, J. GENČI $^{5}$, A. NEČAS ${ }^{6}$, J. SABO $^{2,7}$ \\ ${ }^{1}$ First Department of Surgery, Faculty of Medicine, Pavol Jozef Šafárik University, Košice, \\ Slovakia, ${ }^{2}$ Department of Medical and Clinical Biophysics, Faculty of Medicine, Pavol Jozef Šafárik \\ University, Košice, Slovakia, ${ }^{3}$ University of Prešov, Prešov, Slovakia, ${ }^{4}$ Department of Pathological \\ Physiology, Faculty of Medicine, Pavol Jozef Šafárik University, Košice, Slovakia, \\ ${ }^{5}$ Department of Computers and Informatics, Faculty of Electrical Engineering and Informatics, \\ Technical University of Košice, ${ }^{6}$ Faculty of Veterinary Medicine, University of Veterinary and \\ Pharmaceutical Sciences Brno, Brno, Czech Republic, ${ }^{7}$ Czech Technical University in Prague, \\ University Centre for Energy Efficient Buildings, Buštěhrad, Czech Republic
}

Received August 16, 2019

Accepted October 15, 2019

\begin{abstract}
Summary
The laser radiation absorbed by cells induces production of reactive oxygen species (ROS), followed by the development of oxidative stress. Proteins are major targets for ROS due to their abundance in biological systems. The aim of the present pilot study was to examine the effects of transcutaneous laser blood irradiation (TLBI), i.e., low-level laser therapy (LLLT) at $830 \mathrm{~nm}$ on plasma proteome in Wistar rats. Rats were irradiated in the heart area (i.e. coronary arteries) daily (i.e., for 9-day period), by commercially available GaAsAl diode laser (Maestro/CCM, Medicom Prague, Czech Republic, $\lambda=830 \mathrm{~nm}$, power density $450 \mathrm{~mW} / \mathrm{cm}^{2}$, daily dose $60,3 \mathrm{~J} / \mathrm{cm}^{2}$, irradiation time $134 \mathrm{sec}$ ). The comparison of blood plasma proteome from irradiated and non-irradiated rats was performed utilizing $2 \mathrm{D}$ electrophoresis followed by MALDI TOF/TOF mass spectrometry. LLLT led to a quantitative change in the acute phase proteins with antioxidant protection i.e., haptoglobin ( $\log _{2}$ fold change $(F C)=3.5)$, hemopexin $\left(\log _{2} F C=0.5\right)$, fibrinogen gamma $\left(\log _{2}\right.$ $\mathrm{FC}=1.4)$, alpha-1-antitrypsin $\left(\log _{2} \mathrm{FC}=-2.2\right)$, fetuin $\mathrm{A}\left(\log _{2} \mathrm{FC}=\right.$ $-0.6)$ and fetuin $B\left(\log _{2} F C=-2.3\right)$. In comparison to conventional biochemical methods, the changes in protein levels in blood plasma induced by LLLT offer a deeper insight into the oxidative stress response.
\end{abstract}

\section{Key words}

Low-level laser therapy • Oxidative stress • Acute phase proteins

- Proteomic analysis

\section{Corresponding author}

J. Sabo, Department of Medical and Clinical Biophysics, Faculty of Medicine, P. J. Šafárik University in Košice, Trieda SNP1, SK-04011 Košice, Slovakia. E-mail: jan.sabo@upjs.sk

\section{Introduction}

Low Level Laser Therapy (LLLT) is the medical application of light produced by a low energy laser in the range of 1 to $500 \mathrm{~mW}$ (Huang et al. 2009). Unlike laser surgery, laser therapy utilizes low power laser light without significant thermal effects causing damage to irradiated tissues (Tuner and Hode 1999).

Transcutaneous laser blood irradiation (TLBI) is most commonly used to irradiate areas of the skin near large blood vessels. It is a safe method without any side effects. TLBI is based on blood modification influenced by laser light in order to promote faster and better regeneration. It is generally believed that TLBI affects blood, especially blood cells and plasma proteins (Gasparyan 1998).

The absorption of laser light leads to the production of reactive oxygen species (ROS), being a natural by-product of oxygen metabolism (Kim et al. 2002). They have a key role in cellular signaling pathways from mitochondria to nuclei regulating the nucleic acid synthesis, protein synthesis, enzyme activation, and cell cycle progression (Storz 2007, Brondon et al. 2005). An increase in ROS induces gene expression that is involved in inflammatory and acute phase reactions (APR). One important event in the acute phase reaction is the change in plasma protein molecules known as acute phase proteins (APP) (Eckersall and Bell 
2010). APPs are sensitive markers to assess the status of oxidative stress divided into two groups. Proteins, such as haptoglobin and hemopexin, represent a family of positive plasma proteins in the acute phase (Altruda et al. 1982, Bowman and Kuroski 1985). In contrast, fetuin A and fetuin $\mathrm{B}$ belong to the family of negative plasma proteins in the acute phase (Lebreton et al. 1979). It is believed that abundant proteins can act as physiological antioxidants by protecting other molecules from free radical-mediated oxidation.

In this pilot study, a semi-quantitative method (OD $x$ area) to detect changes in plasma proteins (indicated by $\log _{2}$ fold change) was used. These changes were induced by TLBI on rats (Wistar). Among all identified proteins, the APP were statistically significant $(p \leq 0.05)$ in FGG, HP and HPX which were up-regulated and AHSG, FETUB and SERPINA1 which were downregulated.

\section{Methods}

\section{Animal model}

This experiment was approved by the Ethics Committee of the Faculty of Medicine of P. J. Šafárik University. Each animal experiment was in accordance with the European Guidelines on Laboratory Animal Care. Five-months-old male Wistar rats $(n=8)$, were included in the experiment and randomly assigned into two groups of 4 animals, i.e., the non-irradiated control group (C) and the irradiated group (I).

\section{Low level laser therapy}

Using the trans-cutaneous laser blood irradiation, the rats were daily irradiated in the heart area (i.e., coronary arteries) after shaving the skin with a commercially available gallium-aluminum-arsenium (GaAlAs) diode laser (Maestro/CCM, Medicom Prague, Czech Republic, $\lambda=830 \mathrm{~nm}$, oval shape of beam-spot size $* 1 \mathrm{~cm}^{2}$, power density $450 \mathrm{~mW} / \mathrm{cm}^{2}$, total daily dose $60,3 \mathrm{~J} / \mathrm{cm}^{2}$, irradiation time $134 \mathrm{sec}$ ) for 9 days. During the laser irradiation, all rats were restrained without anasthesia in a tight Plexiglas cage fitted to rat body with a circular opening over the heart area.

\section{Blood collection}

The rats were subjected to general anesthesia [ketamine $40 \mathrm{mg} / \mathrm{kg}$ (Narkamon a.u.v., Spofa, Prague, Czech Republic), xylazine $15 \mathrm{mg} / \mathrm{kg}$ (Rometar a.u.v., Spofa, Prague, Czech Republic), tramadol $5 \mathrm{mg} / \mathrm{kg}$
(Tramadol- K, Krka, Novo Mesto, Slovenia)].

Blood samples were acquired from the heart and collected into a collection tube. Immediately after the blood collection, anticoagulant $\mathrm{Na}_{2}$ EDTA was added to prevent clotting ( $1 \% \mathrm{Na}_{2}$ EDTA in saline). After the blood collection, the tube was immediately placed in an ice bath and delivered for analysis. The blood samples were centrifuged at $2000 \mathrm{~g}$ for $10 \mathrm{~min}$ at $4{ }^{\circ} \mathrm{C}$. Blood plasma was stored at $-80{ }^{\circ} \mathrm{C}$.

\section{Precipitation of plasma protein}

The mixture of plasma $(200 \mu \mathrm{l})$ in $10 \%$ acetone solution of trichloroacetic acid (Sigma Aldrich, St. Louis, USA) was incubated at $-20{ }^{\circ} \mathrm{C}$ for $1 \mathrm{~h}$ and centrifuged at $14000 \mathrm{~g}$ for $5 \mathrm{~min}$ at $4{ }^{\circ} \mathrm{C}$. The supernatant was removed and the ice-cold acetone $(1 \mathrm{ml})$ was added to wash the pellet. The sample was incubated at $4{ }^{\circ} \mathrm{C}$ for $1 \mathrm{~h}$ and centrifuged as described above. The acetone containing supernatant was removed and the pellet was air-dried.

\section{Two-dimensional electrophoresis (SDS-PAGE)}

The protein sample $(50 \mu \mathrm{g})$ was dissolved in rehydratation buffer $(125 \mu \mathrm{l}$, buffer consisting of $7 \mathrm{M}$ urea, $2 \mathrm{M}$ thiourea, $0.035 \mathrm{M}$ Tris-HCl, $2 \% \mathrm{w} / \mathrm{v}$ CHAPS, $65 \mathrm{mM}$ DTT) and loaded onto IPG strip (7 cm strips, $\mathrm{pH}$ 4-7, Bio-Rad, Hercules, CA). The IPG strip was covered with the mineral oil and passive rehydration was permitted during next $12 \mathrm{~h}$ at room temperature. In the next step, the protein mixture was focused in the Protean IEF Cell (Bio-Rad, Hercules, CA) using a voltage program increasing from $0 \mathrm{~V}$ to $250 \mathrm{~V}$ over $1 \mathrm{~h}$, from $250 \mathrm{~V}$ to $4000 \mathrm{~V}$ over $20 \mathrm{~h}$ and kept at $4000 \mathrm{~V}$ for $1 \mathrm{~h}$. The strip was removed from the focusing tray and reduced with $130 \mathrm{mM}$ DTT (Merck, Darmstadt, Germany, $2 \mathrm{ml}$ ) equilibration buffer (6 $\mathrm{M}$ urea, $20 \%$ (v/v) glycerol, $2 \%(\mathrm{w} / \mathrm{v}) \mathrm{SDS}$, and $0.375 \mathrm{mM}$ Tris- $\mathrm{HCl}$ $\mathrm{pH}=8.8$ ) for $10 \mathrm{~min}$. Next, the strip was treated with iodoacetamide (Applichem, Darmstadt, Germany, $2 \mathrm{ml}$ ) in the equilibration buffer for another $10 \mathrm{~min}$. The IPG strip was transferred onto a slab polyacrylamide gel (prepared by the polymerization of $12.5 \%$ acrylamide solution) and overlaid with $0.5 \%$ hot agarose $(1 \mathrm{ml})$ which was allowed to solidify. Electrophoresis was performed in a Protean II cell (Bio-Rad, Hercules,CA) for $1 \mathrm{~h}$ at $200 \mathrm{~V}$ and $400 \mathrm{~mA}$. The gel was taken for staining in Comassie briliant blue G-250 (Bio-Rad, Hercules, CA) for $60 \mathrm{~min}$ followed by washing with water (proteomic grade, $3 \times 20$ minutes). The scanning of the gel was performed on Calibrated Densitometer GS-800 and 
subsequently analyzed with the PDQuest software (Bio-Rad Laboratories USA).

\section{Protein digestion}

Protein spots were cut with EXQuest Spot Cutter (needle id $1.5 \mathrm{~mm}$, Bio-Rad Laboratories, Inc.) and the gel pieces were transferred into the Eppendorf tubes. The color was removed from the gel by washing it with $\operatorname{ACN}(50 \%) / 25 \mathrm{mM}$ ammonium bicarbonate (50\%) buffer $(200 \mu \mathrm{l})$. The supernatant was discarded and ACN (Sigma Aldrich, St. Louis, USA, $100 \mu \mathrm{l}$ ) was added. The gel pieces turned white after $5 \mathrm{~min}$ and $\mathrm{ACN}$ was removed. Next, the gel pieces were air dried and rehydrated in $25 \mathrm{mM}$ ammonium bicarbonate (Applichem, Darmstadt, Germany, $25 \mu \mathrm{l}$ ) containing trypsin (Promega, Medison, USA, $12.5 \mu \mathrm{g}$ ). The mixture was placed in the ice for 1 hour and the remaining trypsin solution was removed. Gel pieces were covered with $25 \mathrm{mM}$ ammonium bicarbonate $(20 \mu \mathrm{l})$ to prevent the gel from drying and the samples were incubated at $37{ }^{\circ} \mathrm{C}$ overnight. The samples were separated by a spinning process and the supernatant was transferred to a $500 \mu \mathrm{l}$ tube. Peptides were extracted with ACN (50\%)/TFA $(1 \%)(2 \times 20 \mu \mathrm{l})$ and the organic layers were combined.

\section{MALDI-TOF MS analysis}

The solution of extracted peptides was mixed with the matrix solution (6 $\mathrm{mg} / \mathrm{ml} \alpha$-cyano-4- hydroxycinnamic acid in acetonitrile/methanol/0.1 \% TFA in water, $84 / 14 / 2 \mathrm{v} / \mathrm{v} / \mathrm{v}$ ) in a proportion of $2: 1$. The $1 \mu \mathrm{l}$ of peptides/matrix mixture was applied onto a MALDI target plate and allowed to dry. Samples were analyzed with the mass spectrometer MALDI TOF/TOF UltrafleXtreme (Bruker Daltonik, Germany). Spectra were acquired in the reflector mode within the range of 700 - 3500 Da. Mass calibration was performed externally with the PepCal (Bruker Daltonik, Germany) standard. The data were evaluated using the Mascot algorithm (Matrix Science Ltd., UK). Mass spectra and tandem mass spectra of peptides were compared against the NCBI database. The search terms were as follows: taxonomy Rattus norvegicus (rat), global modifications Carbamidomethyl (C), variable modifications Oxidation (M), enzyme Trypsin, the number of maximum missed cleavages 1, mass error tolerance $100 \mathrm{ppm}$ in MS and $0.3 \mathrm{Da}$ in $\mathrm{MS} / \mathrm{MS}$ mode. False discovery rate (FDR) $\leq$ $1 \%$, minimum 2 unique peptides.

\section{Results}

Quantitative changes of the spots on the 2D gels in the irradiated group (I) compared to the non-irradiated rats, i.e., the control group (C) were identified. These quantitative changes were indicated by signal intensity per pixel, i.e., optical density (OD) multiplied by the number of pixels in the selected spot (area) (Fig. 1).

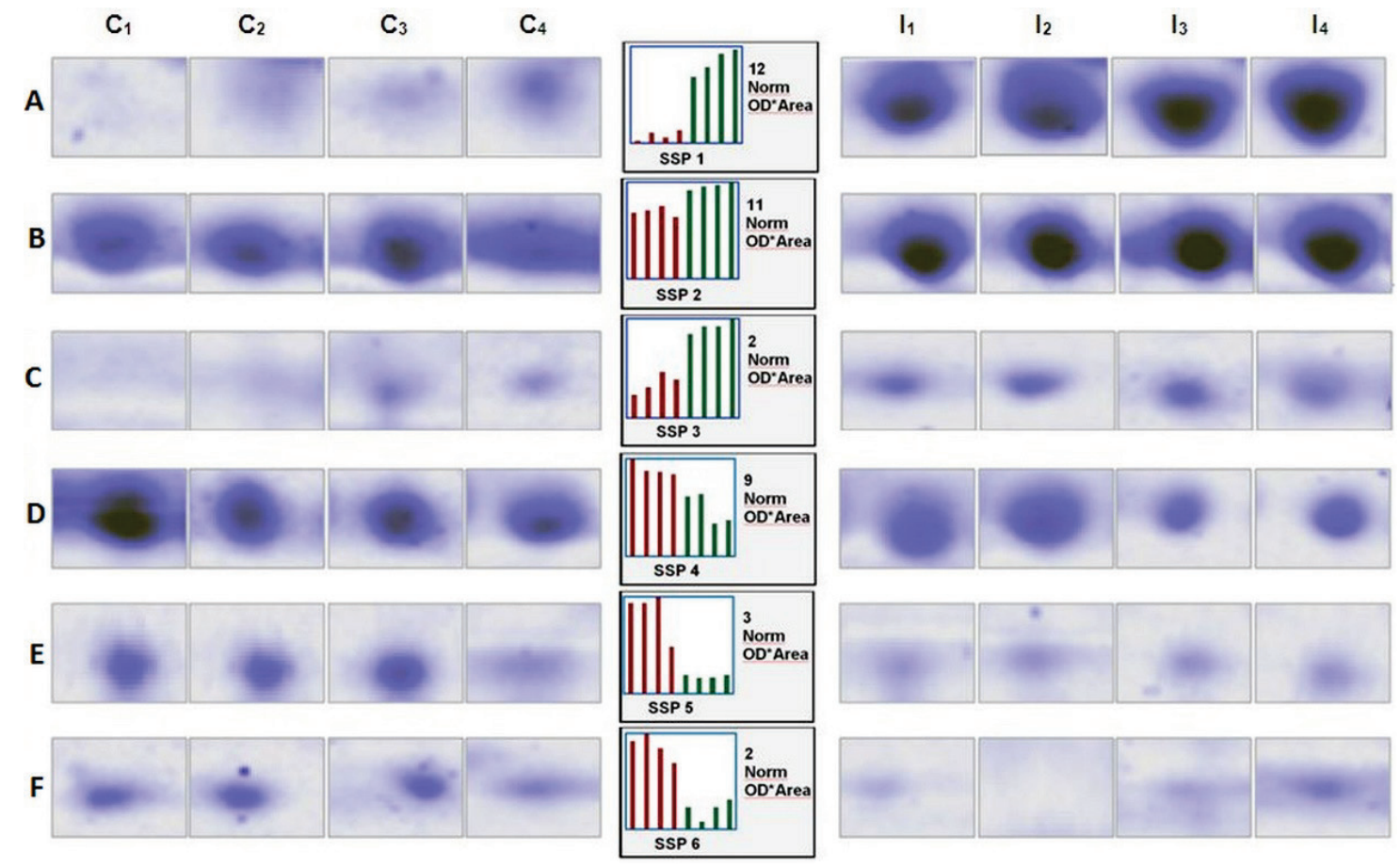

Fig. 1. Semi-quantitative changes $(O D \times$ area) of the plasma proteins for irradiated and non-irradiated rats $A$ - haptoglobin, $B$ - hemopexin, $C$ - fibrinogen gamma, D - fetuin A, E - fetuin B, F - alpha-1-antitrypsin. 
Table 1. Changes in plasma proteins ( $\log _{2}$ fold change) comparing of the non-irradiated and irradiated groups of rats (Wistar) using a semi-quantitative method (OD $x$ area).

\begin{tabular}{|c|c|c|c|c|c|c|c|c|c|c|c|c|}
\hline \multirow[t]{2}{*}{ protein name } & \multicolumn{4}{|c|}{$\begin{array}{c}\text { non-irradiation } \\
\text { (control) group } \\
\text { (OD*Area) }\end{array}$} & \multirow[t]{2}{*}{$\mathbf{C}_{\text {average }} \pm$ SD } & \multicolumn{4}{|c|}{$\begin{array}{l}\text { irradiation group } \\
(\text { OD*Area })\end{array}$} & \multirow[t]{2}{*}{$\mathbf{I}_{\text {average }^{ \pm}} \pm \mathbf{S D}$} & \multirow[t]{2}{*}{$\log 2 \mathrm{FC}$} & \multirow[t]{2}{*}{$\begin{array}{c}\text { t-test } \\
p \leq 0.05\end{array}$} \\
\hline & $\mathrm{C}_{1}$ & $\mathrm{C}_{2}$ & $\mathrm{C}_{3}$ & $\mathrm{C}_{4}$ & & $\mathbf{I}_{1}$ & $\mathbf{I}_{2}$ & $\mathbf{I}_{3}$ & $\mathbf{I}_{4}$ & & & \\
\hline haptoglobin & & & & & $0.98 \pm 0.59$ & & & & & $10.80 \pm 1.46$ & & \\
\hline $\begin{array}{l}\text { hemopexin } \\
\text { fibrinogen }\end{array}$ & 7.5 & 7.8 & 8.3 & 7 & $7.65 \pm 0.54$ & 10.1 & 10.5 & 10.7 & 11 & $10.60 \pm 0.38$ & 0.5 & $1.2 \mathrm{E}-04$ \\
\hline gamma & 0.3 & 0.4 & 0.6 & 0.5 & $0.45 \pm 0.13$ & 1.1 & 1.2 & 1.2 & 1.3 & $1.20 \pm 0.08$ & 1.4 & $6.4 \mathrm{E}-05$ \\
\hline fetuin- $A$ & 8.3 & 7.3 & 7.2 & 7 & $7.45 \pm 0.58$ & 5.1 & 5.3 & 2.8 & 3.1 & $4.80 \pm 1.31$ & -0.6 & $3.2 \mathrm{E}-03$ \\
\hline $\begin{array}{l}\text { fetuin- } B \\
\text { alpha-1- }\end{array}$ & 2.9 & 2.9 & 3.1 & 1.5 & $2.60 \pm 0.74$ & 0.6 & 0.5 & 0.5 & 0.6 & $0.55 \pm 0.06$ & -2.3 & $1.5 \mathrm{E}-03$ \\
\hline antitrypsin & 1.2 & 1.3 & 1.1 & 0.9 & $1.3 \pm 0.17$ & 0.3 & 0.1 & 0.3 & 0.4 & $0.28 \pm 0.13$ & -2.2 & 2.0E-04 \\
\hline
\end{tabular}

SD - standard deviation, FC - fold change, OD - optical density

Subsequently, these spots were cut out of the gel and analyzed quantitatively by MALDI TOF/TOF mass spectrometer.

The calculated values of the $\log _{2}$ fold change of selected blood plasma proteins from the OD $\mathrm{x}$ area of irradiated versus non-irradiated group $\left(\mathrm{I}_{1}+\mathrm{I}_{2}+\mathrm{I}_{3}+\mathrm{I}_{4}\right) /\left(\mathrm{C}_{1}+\mathrm{C}_{2}+\mathrm{C}_{3}+\mathrm{C}_{4}\right)$ were compared using a t-test, $(p \leq 0.05)$. The following quantitative changes of proteins were identified: haptoglobin (HP, $\log _{2}$ fold change=3.5), hemopexin (HPX, $\log _{2}$ fold change $=0.5$ ), fibrinogen gamma (FGG, $\log _{2}$ fold change=1.4), alpha-1antitrypsin (SERPINA1, $\log _{2}$ fold change $=-2.2$ ), fetuin-A (AHSG, $\log _{2}$ fold change=-0.6) and fetuin-B (FETUB, $\log _{2}$ fold change $=-2.3$ ) (Table 1 ).

\section{Discussion}

The exact mechanism at the cellular level by which LLLT stimulates tissue repair and regeneration is still not fully understood. Nevertheless, past research showed evidence that the therapeutic effect depends on the settings of basic laser parameters, such as wavelength, power density, and dose (Grendel et al. 2011). In study of Karu et al. the infrared (IR) laser light at $830 \mathrm{~nm}$ wavelength was reported as the most efficient one in therapeutic applications (Karu et al. 2001). By the lowintensity (1-500 mW) IR laser exposure the protein content and myeloperoxidase activity in blood samples were increased (da Fonseca et al. 2011). Also, by IR laser, the cell proliferation, lipid peroxidation, conformational transitions of red blood cell (RBC) membrane were induced (Grossman et al. 1998, Kujawa et al. 2004). Thus, IR laser irradiation modulates rheological properties and improves microcirculation of blood samples (Ghadage and Kulkarni 2010).

LLLT had lower tissue penetration ability when compared with other energy forms such as ultrasound (USG) or electromagnetic (EM) radiation. However, in IR spectrum superficial chromophores show weak absorption in the window $700-1000 \mathrm{~nm}$, resulting in a deeper energy penetration through the skin compared to a visible light spectrum (Karu 2007).

The invisible infrared light (Ga-As, 600$1200 \mathrm{~nm}$ ) penetrates $2-4 \mathrm{~mm}$ deep in soft tissue whereas the visible light (He-Ne, 400-700 nm) penetrates only 1-2 mm (Robertson et al. 2006). Karu demonstrated that light of $0.01 \mathrm{~J} / \mathrm{cm}^{2}$ influences cellular processes (Karu 1987). Approximately six penetration depths, i.d. about $24 \mathrm{~mm}$ for Gallium-aluminum-arsenide laser $(830 \mathrm{~nm}$, $90 \mathrm{~mW}, 9 \mathrm{~J} / \mathrm{cm}^{2}$ at treatment place) are possible before the beam of light drops from $9 \mathrm{~J} / \mathrm{cm}^{2}$ to $0,01 \mathrm{~J} / \mathrm{cm}^{2}$. As we applied gallium-aluminum-arsenium laser with power density $450 \mathrm{~mW} / \mathrm{cm}^{2}$, we suppose penetration of $0.01 \mathrm{~J} / \mathrm{cm}^{2}$ laser light up to $30 \mathrm{~mm}$, enough for relevant irradiation of tissue and blood.

Therefore, the lasers with IR wavelengths in the above mentioned electromagnetic window are more often used in physiotherapy practice (Enwemeka 2009). It was observed that the $20 \%$ energy penetrated over the rat skin using IR laser $(810 \mathrm{~nm}, 200 \mathrm{~mW})$. However, the important fact is, that this residual penetrating energy is sufficient to reach the radiation dose threshold for 
stimulating tissue repair and physiological processes (Joensen et al. 2012). The blood cells are located deeper under the skin and subcutaneous tissue. Therefore, we suppose that the changes in acute phase proteins observed in this study are the result both TLBI and unknown changes of oxygen metabolism in subcutaneous tissues.

Reactive oxygen species (ROS) induce oxidative stress and quantitative changes in the acute phase proteins. It is known that acute phase proteins can act in the antioxidative defense mechanism. The acute phase protein is defined as a protein whose concentration increases or decreases by at least $25 \%$ during oxidative stress (Gabay and Kushner 1999). Acute phase proteins proved to be successful in the identification of novel mechanisms of cell response against oxidative stress (Keightley et al. 2004).

The main aim of this experiment was to examine the stimulatory effect of LLLT on the change of acute phase proteins acting as antioxidants or antiinflammatory agents in blood plasma. Plasma is not only the cardinal clinical specimen but represents also the largest and most varied fraction of the proteome that is present in the body. The protein profiles of plasma may vary in physiological and pathological conditions (Anderson et al. 2002, Rosenblatt et al 2004). As plasma contains such a variety of proteins in a wide and dynamic concentration range, two-dimensional gel electrophoresis (2-DE) was found to be a useful technique for the separation of such high-complex mixtures (O'Farrell et al. 1975).

In our study the increase of the positive APPs was observed, i.e., haptoglobin $\left(\log _{2} \mathrm{FC}=3.5\right)$, hemopexin $\left(\log _{2} \mathrm{FC}=0.5\right)$ and fibrinogen gamma $\left(\log _{2} \mathrm{FC}=1.4\right)$. The increase of the HP and HPX may be related to hemoglobin released from red blood cell lysis. These proteins act as plasma scavengers of hemoglobin and heme respectively. Thus, they are important for the protection against heme mediated oxidative stress as well as for the prevention of heme-iron loss during the acute phase response (Chiabrando et al. 2011). Fibrinogen gamma binds to platelets and is an essential requirement for platelet aggregation. The increase of the FGG relates to its release from activated platelets induced by laser exposure (da Fonseca et al. 2012).

In conclusion, proteomic studies allow a much broader investigation of LLLT as a cause of the oxidative stress response, as compared to the conventional biochemical methods. Nevertheless, further studies involving proteomic analysis of blood plasma are required to explain the mechanisms of laser biostimulation and clinical trials to optimize irradiation parameters before it becomes an actual method of treatment.

\section{Conflict of Interest}

There is no conflict of interest.

\section{Acknowledgements}

This work was supported by the Agency of the Slovak Ministry of Education for the Structural Funds of the EU, under project ITMS 26220120039, project No. LO1605, by funds of institutional research (TA 29) FVM UVPS Brno and BIONECA COST action CA1622.

\section{References}

ALTRUDA F, POLI V, RESTAGNO G, ARGOS P, CORTESE R, SILENGO L: The primary structure of human hemopexin deduced from cDNA sequence: evidence for internal, repeating homology. Nucleic Acids Res 13: 3841-3859, 1985.

ANDERSON NL, ANDERSON NG: The human plasma proteome: history, character, and diagnostic prospects. Mo Cell Proteomics 1: 845-867, 2002.

BOWMAN BH, KUROSKY A: Haptoglobin: the evolutionary product of duplication, unequal crossing over, and point mutation. Adv Hum Genet 12: 189-261, 1982.

BRONDON P, STADLER I, LANZAFAME RJ: A study of the effects of phototherapy dose interval on photobiomodulation of cell cultures. Lasers Surg Med 36: 409-413, 2005.

DA FONSECA AS, PRESTA GA, GELLER M, DE PAOLI F, VALENCA SS: Low-intensity infrared laser increases plasma proteins and induces oxidative stress in vitro. Lasers Med Sci 27: 211-217, 2012.

ECKERSALL PD, BELL R: Acute phase proteins: Biomarkers of infection and inflammation in veterinary medicine. Vet J 185: 23-27, 2010. 
ENWEMEKA CS: Intricacies of dose in laser phototherapy for tissue repair and pain relief. Photomed Laser Surg 22: 387-393, 2009.

GABAY C, KUSHNER I: Acute-phase proteins and other sys-temic responses to inflammation. $N$ Engl J Med 340: 448, 1999.

GASPARYAN L: Investigation of sensations, associated with laser blood irradiation. In: Walt 2-nd Congress, Kansas City, USA, 1998, pp 87-88.

GHADAGE V, KULKARNI GR: Effects of Nd:YAG laser irradiation on human erythrocytes in vitro. Int J Integr Biol 9: 149-151, 2010.

GRENDEL T, SOKOLSKÝ J, VAŠČÁKOVÁ A, HREBOVÁ B, POLÁKOVÁ M, BOBROV N, SABOL F, GAL P: Low-level laser therapy (LLLT) at $830 \mathrm{~nm}$ positively modulates healing of tracheal incisions in rats: A Preliminary Histological Investigation. Photomed Laser Surg 29: 613-618, 2011.

GROSSMAN N, SCHNEID N, REUVENI H, HALEVY S, LUBART R: $780 \mathrm{~nm}$ low power diode laser irradiation stimulates proliferation of keratinocyte cultures: involvement of reactive oxygen species. Lasers Surg Med 22: 212-218, 1998.

HUANG YY, CHEN AC, CARROLL JD, HAMBLIN MR: Biphasic dose response in low level light therapy. Dose Response 7: 358-383, 2009.

JOENSEN J, OVSTHUS K, REED RK, HUMMELSUND S, IVERSEN VV, LOPES-MARTINS RÁ, BJORDAL JM: Skin penetration time-profiles for continuous $810 \mathrm{~nm}$ and Superpulsed $904 \mathrm{~nm}$ lasers in a rat model. Photomed Laser Surg 30: 688-694, 2012.

KARU TI: Photobiological fundamentals of low power laser therapy. IEEE J Quantum Electron.: QE-23: 1703-1717, 1987.

KARU TI, AFANASYEVA NI, KOLYAKOV SF, PYATIBRAT LV, WELSER L: Changes in absorbance of monolayer of living cells induced by laser radiation at 633, 670 and $820 \mathrm{~nm}$. IEEE J Sel Top Quant 7: 982-988, 2001.

KARU TI: Ten lectures on basic science of laser phototherapy. In: Prima Books AB, Grangesberg, Sweden, 2007, pp 414.

KEIGHTLEY JA, SHANG L, KINTER M: Proteomic analysis of oxidative stress-resistant cells: a specific role for aldose reductase overexpression in cytoprotection. Mol Cell Proteomics 3: 167-175, 2004.

KIM YG: Laser-mediated production of reactive oxygen and nitrogen species, implications for therapy. Free Rad Res 36: 1243-1250, 2002.

KUJAWA J, ZAVODNIK L, ZAVODNIK I, BUKO V, LAPSHYNA A, BRYSZEWSKA M: Effect of low-intensity $\left(3.75-25 \mathrm{~J} / \mathrm{cm}^{2}\right)$ near-infrared $(810 \mathrm{~nm})$ laser radiation on red blood cell ATPase activities and membrane structure. J Clin Laser Med Surg 22: 111-117, 2004.

LEBERTON JP, JOISEL F, RAOULT JP, LANNUZEL B, ROGEZ JP, HUMBERT G: Serum concentration of human alpha 2 HS glycoprotein during the inflammatory process. Evidence that alpha2 HS glycoprotein is a negative acute-phase reactant. J Clin Invest 64: 1118-1129, 1979.

O'FARELL PH: High resolution two-dimensional electrophoresis of proteins. J Bio Chem 250: 4007, 1975.

ROBERTSON V, WARD A, LOW J, REED A: Electrotherapy Explained Principles and Practice. In: Elsevier. London, United Kingdom, 2006.

ROSENBLATT KP, BRYANT GP, KILLIAN JK, MEHTA A: Serum proteomics in cancer diagnosis and management. Annu Rev Med 55: 97-112, 2004.

STORZ P: Mitochondrial ROS--radical detoxification, mediated by protein kinase D. Trends Cell Biol 17: 13-18, 2007.

TUNER J, HODE L: Low Level Laser Therapy: Clinical Practice and Scientific Background. In: Prima Books. Grängesberg, Sweden, 1999.

VINCHI DCF, FIORITO V, TOLOSANO E: Haptoglobin and Hemopexin in Heme Detoxification and Iron Recycling. In: Acute Phase Proteins - Regulation and Functions of Acute Phase Proteins. VEAS F (eds), Montpellier, France, 2011, pp 261-288. 